\title{
Effect of a horse's month of birth on its future sport performance. II. Effect on annual earnings and annual earnings per start
}

\author{
Bertrand Langlois ${ }^{*}$, Christine Blouin
}

Station de génétique quantitative et appliquée, Inra, 78352 Jouy-en-Josas cedex, France

(Received 18 July 1997; accepted 6 November 1997)

\begin{abstract}
This study examines the effect of month of birth and its interactions with sex, age and year of performance for performance in flat races, jumping races (steeple-chases and hurdle races), trotting races, and equestrian competitions (jumping, eventing, dressage). The level of performance was evaluated by considering the logarithm of annual earnings and the logarithm of annual earnings per start in each discipline. Significant interactions were found between age and sex in all racing disciplines and in jumping. In some cases, a significant interaction also appeared between month of birth and sex. This was ignored in our previous study. Taking this factor into account, however, does not change the conclusions of this article very much, although it allows a greater precision of the estimates. For example, the decrease of the effect of month of birth with increasing age is only significant for racing disciplines. This finding supports the idea that the effect of month of birth in racing horses results mainly from real age differences between horses from the same 'administrative' age class. Any lingering effect in horses older than 4 years seems to be stable and of smaller magnitude. For these adult horses the effect of age differences in month is expected to tend to zero and performance differences according to the month of birth remaining at this stage could therefore result from a seasonal effect, stable during the life of the animal. (C Elsevier / Inra.)
\end{abstract}

horse / month of birth effect / sport performance

Résumé - Effet du mois de naissance sur les performances des chevaux. II. Effet sur le gain annuel et le gain moyen annuel par départ. Cette étude examine l'effet du mois de naissance en tenant compte de ceux du sexe, de l'âge et de l'année de la performance ainsi que les interactions entre tous ces effets sur les performances en courses plates, à obstacles, au trot et dans les compétitions équestres (concours de saut d'obstacles, concours complet d'équitation, concours de dressage). La performance est évaluée par le Log du gain annuel et le Log du gain moyen annuel par départ dans chaque discipline. Des interactions significatives ont été trouvées entre l'âge et le sexe pour toutes les disciplines de courses et pour le concours de saut d'obstacles. Dans cer-

* Correspondence and reprints 
tains cas, une interaction significative apparait entre l'effet du mois de naissance et le sexe. Elles étaient ignorées dans l'étude précédente (partie I). Toutefois, leur prise en compte ne modifie pas beaucoup les conclusions mais donne plus de précision. Par exemple, la décroissance de l'effet du mois de naissance avec l'augmentation de l'âge n'est significative que dans le cas des courses. Mais au-delà de 4 ans, à mesure que les chevaux deviennent adultes, l'effet qui subsiste et qui paraît stable et de moindre amplitude ne peut plus raisonnablement être attribué à une différence d’âge de quelques mois, on ne peut alors exclure de l'attribuer à un effet de saison. (@ Elsevier / Inra.)

\section{cheval / effet du mois de naissance / performance sportive}

\section{INTRODUCTION}

The results presented in a previous paper [7] involved the use of a very simple model (with one fixed effect: month of birth) on previously adjusted data (annual phenotypic indexes). They revealed the possibility of interactions between age and month of birth without actually testing it. Because corrections for age and sex in the annual phenotypic indexes are made within a given performance year, they account for all interactions within this latter factor. In previous studies [3-6], however, the possibility of interaction between sex and age was ignored. As this interaction could be significant over a longer period, it was decided to test this interaction more thoroughly through further analysis of the unadjusted data. In the current paper, we examined the effect of month of birth in relation to those of sex, age and year of performance and all possible twoway interactions between these factors using the log of annual earnings (LAE) and the $\log$ of annual earnings per start (LAE/S) in flat races, jumping races, trotting races and equestrian competitions (jumping, eventing, dressage).

\section{MATERIALS AND METHODS}

\subsection{Measure of the performance}

It is now very common to transform the earnings to get normally distributed values. A long time ago $[3,4]$ we proposed to use log transformations because of the exponential decrease of earnings according to the rank in the competition and because the total purse allocated for each event approaches a normal log distribution. Other authors $[1,2,8]$ have recommended power transformations. There are also variance stabilizing transformations which lead to similar effects. In the case of horses that do not earn any money, Arnason et al. [1] and Klemetsdal [2] have proposed to add one to the earnings before log transformation. This gives all horses that do not earn any money the same value and may therefore introduce an artificial resemblance between them and bias the analysis. We prefer to consider the zero earners as non-tested horses even in the rare case when they started many times without success.

In this study, the two variables retained to measure the performance are the log of the annual earnings (LAE) in a given discipline and the log of annual earnings per start (LAE/S). The trait units are 1/20 of the standard error of the model, and the intercept was set equal to 100 in order to make comparisons easier with the first part of our study [7].

\subsection{Model}

Data were fitted to the following model using general linear models procedure of SAS [9]:

$$
\begin{gathered}
y_{i j k l}=\mu+s_{i}+a_{j}+y_{k}+m_{1}+s a_{i j}+s y_{i k}+s m_{i l} \\
+a y_{j k}+a m_{j l}+y m_{k l}+e_{i j k l}
\end{gathered}
$$

where: $y_{i j k l}$ is the dependent variable (LAE or $\mathrm{LAE} / \mathrm{S}) ; \mu$ the intercept, defined as the mean, value in the year 1994, of males and geldings born in April and having 3 years of age in flat and trotting races, 4 years of age in jumping races, or 8-10 years of age in equestrian competitions (jumping, eventing, dressage); $s_{i}$ the effect of sex (two levels: males and geldings, females); $a_{\text {t }}$ the effect of age with four levels ( 2 , $3,4,>5$ year-old) in flat races, four levels ( 3 , 
$4,5,>6$ year-old) in jumping races, five levels $(2,3,4,5,>6$ year-old $)$ in trotting races, five levels $(4,5,6-7 ; 8-10 ;>11$ year-old) in jumping, four levels $(4-5,6-7,8-10 ;>11$ yearold) in eventing and dressage; $y_{k}$ is the effect of year of performance (10 levels: from 1985 to 1994); $m_{1}$ the effect of month of birth (five levels: January-February, March, April, May, June and later). For flat races, some horses born in December in the preceding year are included in the January-February level; $s a_{i j}$ is the interaction between sex and age; $s y_{i k}$ is the interaction between sex and year of performance; $\mathrm{sm}_{\mathrm{il}}$ is the interaction between sex and month of birth; $\mathrm{ay}_{\mathrm{jk}}$ is the interaction between age and year of performance; $a m_{j l}$ is the interaction between age and month of birth; $\mathrm{ym}_{\mathrm{kl}}$ is the interaction between year of performance and month of birth; and $e_{i j k l}$ is a residual error. The numbers of observations in each data set are given in table I.

\section{RESULTS}

The results of analyses of variance are reported in table I. All main effects (sex, age, year of performance and month of birth) were highly significant $(P<0.001)$ whatever the discipline examined for the two variables studied. A highly significant $(P<0.01)$ interaction occurred between age and sex in the case of races and jumping for the two variables.

A highly significant interaction between sex and year of performance only occurred for the variable $\mathrm{LAE} / \mathrm{S}$ in jumping races and in dressage. This suggests some differences in the number of starts between males or geldings and females in these disciplines.

Highly significant interactions also appeared between age and year of performance except for jumping races and LAE/S in dressage and annual earnings in flat races. These interactions suggest an evolution in the policy of earnings distribution mainly in trotting races and equestrian competitions.

Highly significant interactions were found between month of birth and age in racing disciplines and for $\mathrm{LAE} / \mathrm{S}$ in eventing. Some significant interactions $(P<0.05)$ between month of birth and sex may also occur for only one of the two variables, for example in jumping races, trotting races and dressage.

No statistically significant interaction was found between month of birth and year of performance.

The estimates of month of birth effects are reported in tables II to VIII; the estimates of combined effects of month of birth and one other factor (sex, age) are given only when month of birth interacts with this factor in a significant manner $(P<0.05)$.

Effects of age and year of performance were not taken into account optimally through this model because the effect of year includes the effect of genetic progress and the effect of age includes that of selection on earlier performance level. This problem was discussed by Tavernier $[10$, 11].

The effect of sex is well known and will not be discussed here. The mean advantage of an early birth in the year (January-February) was very noticeable (table VIII) in flat races (five points). It was not so important for jumping races where there was only a slight advantage for foals born in March (two points). For trotting races, the advantage of an early birth was nearly equivalent for foals born in January-February or March (2.5-2 points) and was not as large as in flat races.

The disadvantage of being born late in the year (June and later) for flat races $(-5$ points) was not so marked in jumping races or for trotters ( -2 points).

Highly significant interactions of month of birth with age for both traits demonstrated a decrease of the effect of month of birth with age in all racing disciplines. Interactions of month of birth with sex concerned jumping races (LAE) and trotting races (LAE/S). In these two cases, 


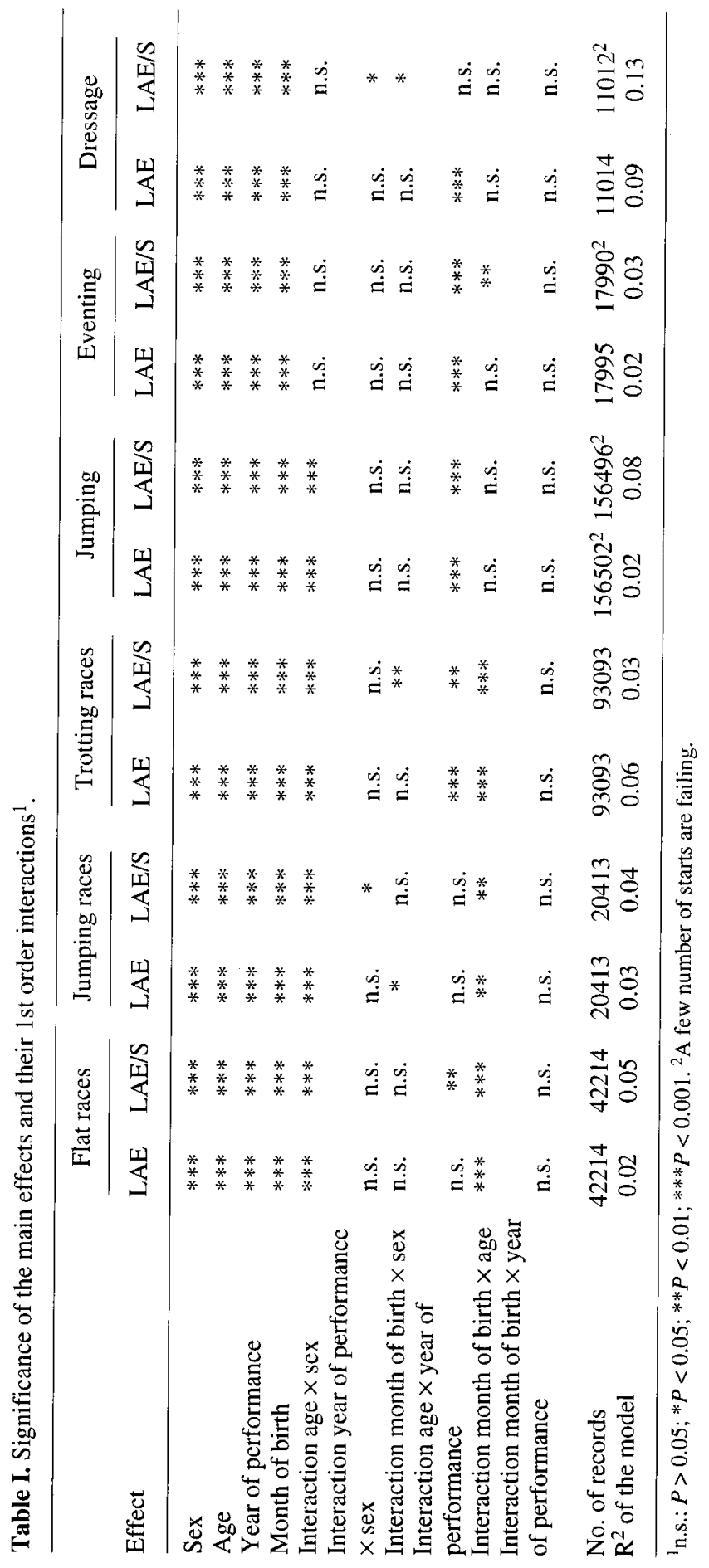


Table II. Effect of month of birth according to age on LAE and LAE/S in flat races.

\begin{tabular}{llccc}
\hline & \multicolumn{3}{c}{ Age } \\
\cline { 2 - 5 } Month of birth & 2-year-olds & 3-year-olds & 4-year-olds & > 5-year-olds \\
\hline LAE & & & & \\
January-February & 10.3 .6 & 104.5 & 103.4 & 101.1 \\
March & 102.3 & 102.7 & 102.0 & 101.4 \\
April & 100.0 & 100.0 & 100.0 & 100.0 \\
May & 98.8 & 98.9 & 99.7 & 99.9 \\
June and later & 93.6 & 94.9 & 96.9 & 98.3 \\
LAE/S & & & & \\
January-February & 105.4 & 105.7 & 103.9 & 101.2 \\
March & 103.4 & 103.7 & 103.2 & 102.2 \\
April & 100.0 & 100.0 & 100.0 & 100.0 \\
May & 98.3 & 98.9 & 99.6 & 99.5 \\
June and later & 95.2 & 94.7 & 96.6 & 97.4 \\
\hline
\end{tabular}

Table III. Effects of month of birth according to age and to sex on LAE and LAE/S in jumping races.

\begin{tabular}{|c|c|c|c|c|c|c|}
\hline \multirow[b]{2}{*}{ Month of birth } & \multicolumn{4}{|c|}{ Age } & \multicolumn{2}{|c|}{ Sex } \\
\hline & $\begin{array}{l}\text { 3-year- } \\
\text { olds }\end{array}$ & $\begin{array}{l}\text { 4-year- } \\
\text { olds }\end{array}$ & $\begin{array}{l}\text { 5-year- } \\
\text { olds }\end{array}$ & $\begin{array}{l}>\text { 6-year- } \\
\text { olds }\end{array}$ & Females & $\begin{array}{l}\text { Males and } \\
\text { geldings }\end{array}$ \\
\hline \multicolumn{7}{|l|}{ LAE } \\
\hline January-February & 100.0 & 100.0 & 101.1 & 98.4 & 97.0 & 100.0 \\
\hline March & 101.7 & 101.7 & 100.0 & 100.6 & 96.1 & 101.7 \\
\hline April & 100.0 & 100.0 & 100.0 & 100.0 & 100.0 & 100.0 \\
\hline May & 96.4 & 97.7 & 98.6 & 99.5 & 93.1 & 97.7 \\
\hline June and later & 95.3 & 97.8 & 100.3 & 100.8 & 92.4 & 97.8 \\
\hline \multicolumn{7}{|l|}{$\mathrm{LAE} / \mathrm{S}$} \\
\hline January-February & 101.2 & 101.7 & 102.0 & 99.2 & & \\
\hline March & 102.5 & 102.2 & 102.4 & 100.5 & & \\
\hline April & 100.0 & 100.0 & 100.0 & 100.0 & & \\
\hline May & 96.7 & 97.3 & 98.0 & 98.6 & & \\
\hline June and later & 95.6 & 95.4 & 98.9 & 98.3 & & \\
\hline
\end{tabular}

the effect of month of birth was more marked in females.

For equestrian competitions, the highly significant effect of month of birth was of much smaller magnitude for jumping where a slight advantage was observed for foals born in March (0.2-0.4 points). For the eventing, an advantage for foals born in April appeared in contrast to a cor- 
Table IV. Effect of month of birth according to age and to sex on LAE and LAE/S in trotting races.

\begin{tabular}{|c|c|c|c|c|c|c|c|}
\hline \multirow[b]{2}{*}{ Month of birth } & \multicolumn{5}{|c|}{ Age } & \multicolumn{2}{|c|}{$\operatorname{Sex}$} \\
\hline & $\begin{array}{l}\text { 2-year- } \\
\text { olds }\end{array}$ & $\begin{array}{l}\text { 3-year- } \\
\text { olds }\end{array}$ & $\begin{array}{l}\text { 4-year- } \\
\text { olds }\end{array}$ & $\begin{array}{c}\text { 5-year- } \\
\text { olds }\end{array}$ & $\begin{array}{c}>6 \text {-year- } \\
\text { olds }\end{array}$ & Females & $\begin{array}{c}\text { Males and } \\
\text { geldings }\end{array}$ \\
\hline \multicolumn{8}{|l|}{ LAE } \\
\hline January-February & 102.5 & 102.4 & 102.4 & 99.1 & 101.3 & & \\
\hline March & 101.5 & 101.9 & 101.9 & 100.6 & 100.3 & & \\
\hline April & 100.0 & 100.0 & 100.0 & 100.0 & 100.0 & & \\
\hline May & 99.3 & 99.2 & 98.8 & 98.6 & 99.7 & & \\
\hline June and later & 98.8 & 97.6 & 98.7 & 98.5 & 99.7 & & \\
\hline \multicolumn{8}{|l|}{ LAE/S } \\
\hline January-February & 102.3 & 102.6 & 102.5 & 99.5 & 104.2 & 100.8 & 102.6 \\
\hline March & 101.8 & 102.2 & 101.8 & 100.8 & 100.3 & 99.8 & 102.2 \\
\hline April & 100.0 & 100.0 & 100.0 & 100.0 & 100.0 & 100.0 & 100.0 \\
\hline May & 98.7 & 98.8 & 98.2 & 98.1 & 99.0 & 97.6 & 98.8 \\
\hline June and later & 97.8 & 97.8 & 98.3 & 98.5 & 99.6 & 95.6 & 97.8 \\
\hline
\end{tabular}

Table V. Effect of month of birth on LAE and $\mathrm{LAE} / \mathrm{S}$ in jumping.

\begin{tabular}{lrr}
\hline Month of birth & LAE & LAE/S \\
\hline January-February & 99.8 & 100.2 \\
March & 100.4 & 100.2 \\
April & 100.0 & 100.0 \\
May & 99.8 & 99.4 \\
June and later & 99.7 & 100.0 \\
\hline
\end{tabular}

responding disadvantage of being born either too early or too late in the year. The significant interaction of age with LAE/S increased mainly for horses older than 11 years and did not decrease with age as was the case for races.

For dressage, the advantage of horses born in January-February (three points) or in June and later (four points) was more marked for LAE/S in females than in males and geldings (table VII). It is difficult to understand the reasons behind this effect. They may be revealed by using more complete models, including individual horse effects.

Table VI. Effects of month of birth on LAE and, according to age, on LAE/S in eventing.

\begin{tabular}{lccccc}
\hline Month of birth & LAE & \multicolumn{4}{c}{ LAE/S } \\
\cline { 3 - 5 } & & $\begin{array}{c}4-5 \text { year } \\
\text { olds }\end{array}$ & $\begin{array}{c}6-7 \text { year } \\
\text { olds }\end{array}$ & $\begin{array}{c}\text { 8-10 year } \\
\text { olds }\end{array}$ & $\begin{array}{c}\text { > 11 year } \\
\text { olds }\end{array}$ \\
\hline January-February & 97.8 & 98.9 & 100.5 & 99.0 & 94.7 \\
March & 99.1 & 96.7 & 98.1 & 98.3 & 96.9 \\
April & 100.0 & 100.0 & 100.0 & 100.0 & 100.0 \\
May & 96.8 & 98.0 & 99.5 & 97.2 & 95.8 \\
June and later & 94.3 & 96.2 & 96.5 & 95.2 & 92.9 \\
\hline
\end{tabular}



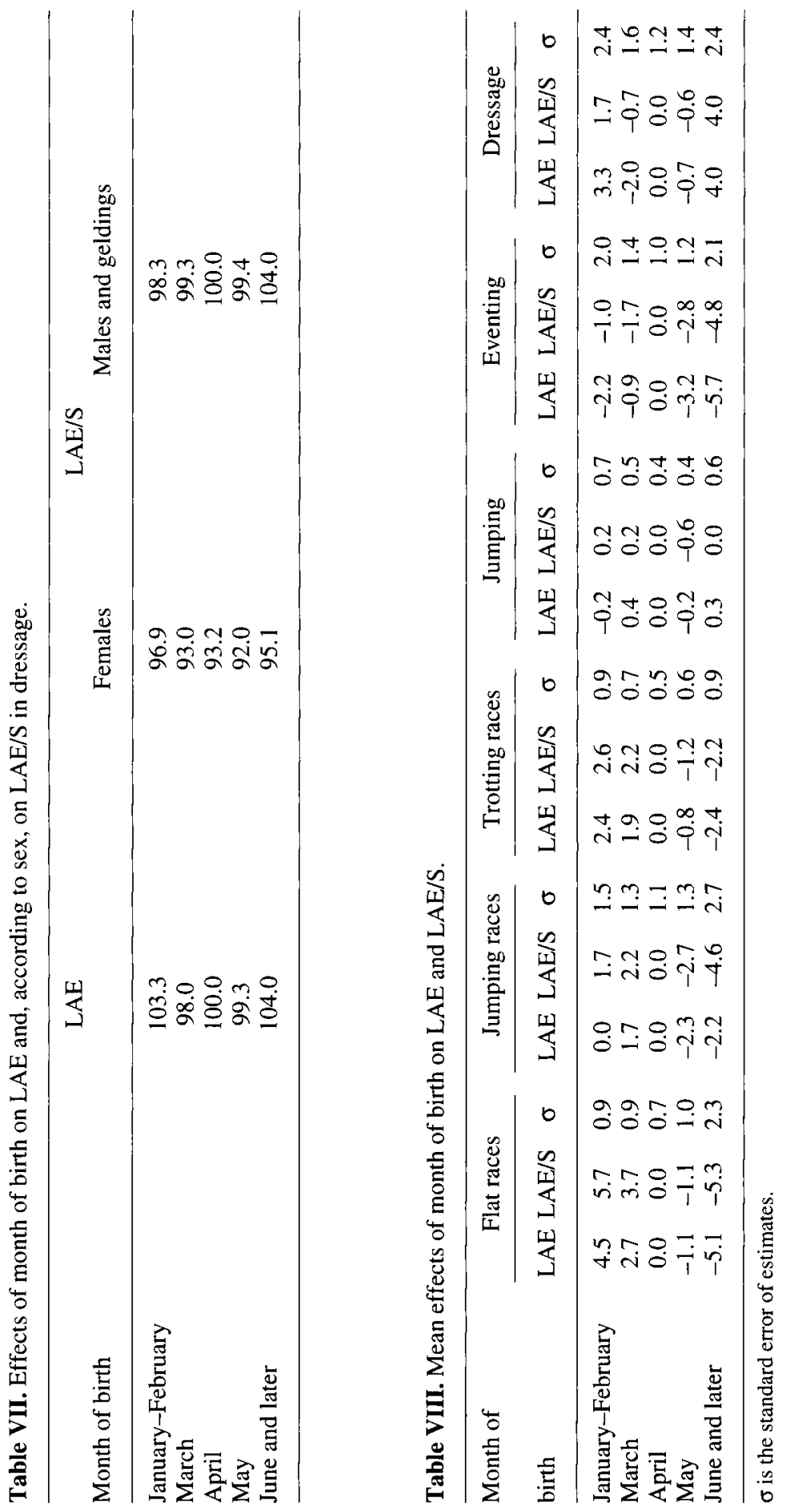


\section{DISCUSSION AND CONCLUSION}

The effect of month of birth on a horse's future sport performance described in Langlois and Blouin [7] for annual phenotypic indices was confirmed here with a more complete model based on data that were the $\log$ of annual earnings and the $\log$ of annual earnings per start.

The decrease of this effect with age was demonstrated only for races where early born horses are favored. Except for eventing (LAE/S) no evolution of this effect with age was demonstrated for equestrian competitions. These two situations suggest that two phenomena may be involved in the month of birth effect. The first one is the effect of real age differences in the same 'administrative' age class. This effect can be supposed to decrease with advancing age.

The second one is a seasonal effect. It can also be hypothesized that this part of the effect would remain stable during the life of the horse or even would increase with advancing age as the competitions become more difficult, as in the case of eventing.

However, this second part of the effect, revealed only when the horses are adults, seems of smaller magnitude. It mainly refers to equestrian competitions involving older horses. In theory, this very highly significant effect should be corrected for breeding value estimations. However, its small magnitude indicates that it will probably not change the results and therefore, in practice corrections are probably not necessary.

For races, however, the first part of the effect is of larger magnitude. This should definitely be taken into account for breeding value estimation. This could be done either by correcting for the real age at the time of performance measurement, or by taking into account the effect of month of birth, when performance is measured by summarized data at the year level. The latter would be the simplest way to replace the currently imprecise 'administrative' age class.

\section{REFERENCES}

[1] Arnason T., Bendroth M., Philipsson J., Henriksson K., Darenius A., Genetic evaluations of Swedish trotters, In: State of breeding evaluation in trotters, EAAP Publication no. 42, Pudoc, Wageningen, 1989, 106-130.

[2] Klemetsdal G., Norwegian trotter breeding and estimation of breeding values, In: State of breeding evaluation in trotters, EAAP Publication no. 42, Pudoc, Wageningen, 1989, 95-105.

[3] Langlois B., Analyse statistique et génétiques des gains des pur sang anglais de trois ans dans les courses plates françaises, Ann. Génét. Sél. Anim. 7 (1975) 387-408.

[4] Langlois B., Interprétation statistique et génétique des gains des chevaux dans les compétitions équestres françaises, Livest. Prod. Sci. 2 (1975) 191-204.

[5] Langlois B., Estimation de la valeur génétique des chevaux de sport d'après les sommes gagnées dans les compétitions équestres françaises, Ann. Génét. Sél. Anim. 12 (1980) 15-31.

[6] Langlois B., Breeding evaluation of French trotters according to their race earnings. Present situation, In: EAAP Publication no. 42, Pudoc, Wageningen, 1989, 27-40.

[7] Langlois B., Blouin C., Effect of a horse's month of birth on its future sport performance. I. Effect on annual phenotypic indices, Ann. Zootech. 46 (1997) 393-398.

[8] Minkema D., Studies on the genetics of trotting performance in Dutch trotters. I. Heritability of trotting performance, Ann. Génét. Sél. Anim. 7 (1975) 99-121.

[9] SAS, SAS/STAT User's guide, version $6,4^{\text {th }}$ edition, volume 2, GLM Procedure, 1989, 891-993.

[10] Tavernier A., Caractérisation de la population des Trotteurs Français d'après leur estimation génétique par un Blup modèle animal, Ann. Zootech. 38 (1989) 145-155.

[11] Tavernier A., Caractérisation des chevaux de concours hippique français d'après leur estimation génétique par un Blup modèle animal, Ann. Zootech. 39 (1990) 27-44. 